\title{
旧甲州街道台ヶ原宿の町並と住居形式に関する研究 \\ A STUDY ON TRANSITION OF ROWS OF TOWN HOUSES AND THEIR TYPES IN DAIGAHARA ALONG THE OLD ROUTE OF KOSHU-KAIDO
}

\author{
渡辺洋子*，伊藤裕 久** \\ Yoko WATANABE and Hirohisa ITO
}

\begin{abstract}
This paper focuses on Daigahara Town in Yamanashi Prefecture, where traditional town dwellings are still surviving along the Kinsei route of Koshu-Kaido. Daigahara was established as a medieval 'shuku' beforethe highway route was modified in the early 17th century. After the modification, Daigahara was moved to the present position, and during the Edo Period, the town progressed to a high prosperity.

In this study, surveys were carried out on 8 town houses and on historical documents, for example,scrolls of land-tenure registration. Among these town houses, there is Kitahara House built in 19th Century, on a large dwelling-lot after accumulation of land-tenure. This House has also preserved a number of historical documents and old site plans.

The first procedure of this paper is to clarify historical stages of dwelling-lots, comparing with each stage, and to grasp transition of landtenure. The second is to classify house types of dwellings after reconstructing original form of each house. Consequently, a tendency is inferred on the relationship between the historical stage of land-tenure and the chronological change of house types, which leads to a conclusion that in Daigahara traditional dwellings might be attributed to two different house types developed on each form of dwelling-lots.
\end{abstract}

Key Words : Koshu-Kaido, Daigahara Town, rows of town houses, land-tenure registration, dwellings; physiognomy plan of a house 甲州街道、台ヶ原宿、町並、検地帳、住居、家相図

\section{1.はじめに}

本研究は甲州武川筋の台ヶ原 (現・山梨県北巨摩郡白州町台ヶ原) を取り上げる。台ヶ原は山梨県の北西端、白州町の最東端に位㯰し、 金無川とその支流の尾白川の合流地点、信州往還 (甲州街道) と逸見 路を結ぶ交通の要衝に立地する。永禄11年(1568)「武田氏伝馬口付 銭」”に「従府中台原へ四十文、従台原蔦木一十五文、(以下略)」

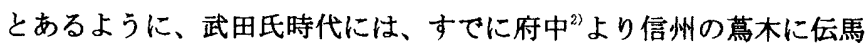
を継立するための重要な宿を形成していた。また、南側には尾白川 を挟んで武川鼻の軍事的拠点であった中山砦が存在し「根苦豦」地 名がみられる゙など、その山麓に展開した宿の一類型と考えることも 可能である。この時の集落は慶長 7 年以降(の甲州街道付替による宿 駅整備以前に成立していた中世の宿（台ヶ原元宿）を指寸と考えられ、 その立地は現在の台ヶ原よりおよそ0.8km東に位置し、明治 26 年 （1893）「北巨摩郡菅原村之内大字台ヶ原組全図」 ${ }^{5} に$ 「古屋敷」とい う小字名で示され(図 1)、現在は耕作地となっている。

現在の台ヶ原は甲州街道が五街道の一として整備され、付替えら れてから後に移転・整備された宿であり、小字名では「屋敷」に相 当する。後年とりわけ明和年間 (1764 72) から幕府、代官所、諸家 らによる往来が増加し、さらに天明 3 年 (1783) の浅間山噴火によっ て通行困難となった中山道の人馬まで甲州街道に流入したため、
近世後期から幕末にかけて街道は大きく繁栄し、宿が発展した

本稿ではまず前段において慶長 6 年 (1601) 「武川筋臺ヶ原郷屋敷 御縄打水帪」および寛文12年 (1672) 「甲州武川筋臺ヶ原村屋敷御検 地水帳」”によって宿の屋敷地割の状況を分析し、さらに幕末期の古 絵図に基づく屋敷地割復原図との比較を試みることて、、屋䑤 (宅地) の変遷を時代を追って明らかにする。さらに後段では台ヶ原宿にお いて建設年代が 1700 年 1927 年に分散する 8 棟の町屋住居を選定し、 実測調查の結果に基づき建物現状、建設年代、当初復原平面を把握 する。最終的に屋敷の形態と住居の復原平面形式との関係性を問い、 町並が構成された経緯を通時的に推察することを目的とする8)。なお 昭和34年の台風被害後、再整備された甲州街道新道が台ヶ原を外れ たため、近世の旧甲州街道 ${ }^{9}$ は県道となり、旧来の町並が残っている。

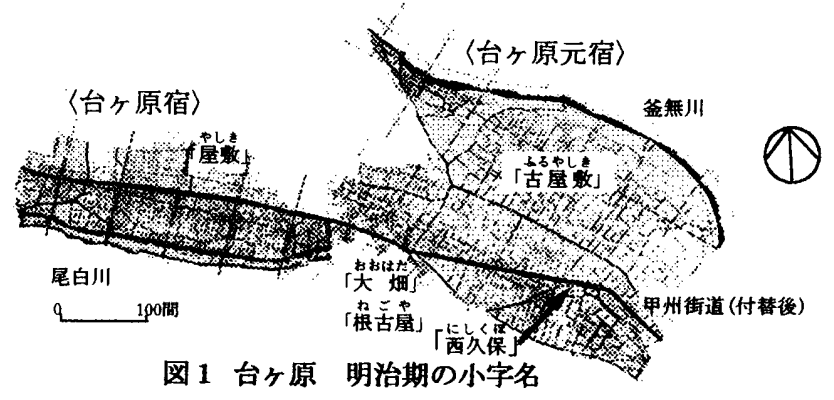

* 芝浦工業大学工学部建築工学科 教授・工博

** 東京理科大学二学部建築学科 助教授 $\cdot$ 工工博
Prof., Dept. of Architecture and Building Construction, Faculty of Engineering, Shibaura Institute of Technology, Dr. Eng.

Assoc. Prof., Dept. of Architecture, Faculty of Engineering, Science University of Tokyo, Dr. Eng. 


\section{2. 台ヶ原宿の屋僌地割復原}

\section{1 台ヶ原元宿における慶長 6 年 (1602) 屋敷規模復原}

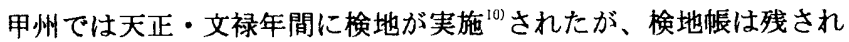
ておらず、一方、慶長の検地帳 ${ }^{11}$ が多くの村方に残っで ${ }^{21}$ 「慶長古 高」と呼ばれ、寛文年間以降の検地が実施されるまで村方支配の基 礎となっていた。慶長 6 年 (1601)「武川箭臺ヶ原郷屋敷御緡打水 帳」もそのような慶長検地帳の一冊であり ${ }^{132}$ 、甲州街道整備以前の宿 である、台ヶ原元宿の地割を丈量したと考えられる。同史料では屋 敷 (宅地) 分が記載され、屋敷一筆ごとに敷地の閒口および奥行(間)、

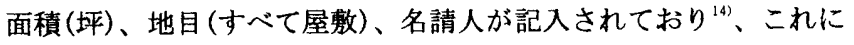
基づいて分析を行った。

表 1 によると間口が狭く(3〜 5間)、奥行が深い(10〜28間) 屋敷が、 全体の $68 \%$ と圧倒的に多いことがわかる。逆に、間口が奥行よりも 広い屋敷は $10 \%$ にすぎない。この結果から、慶長期には閒口平均 4 間前後の細長い短冊形屋敷が一般的であったことがわかる。

\section{2 台ヶ原宿における筧文12年 (1672) 屋敷規模復原}

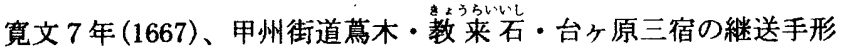
により菲崎一蕹木宿間の街道人馬継立方式が成立した ${ }^{15)}$ 。その 5 年後 の検地による寛文12年 (1672)「甲州武川筋喜ヶ原村御検地水帳」 ${ }^{18)}$ に おいても、前述の慶長 6 年史料と同様の屋敷分の記載がある ${ }^{17}$ 。街道 整備・移転後の台ヶ原の地割について、同史料により分析を行った。 表 2 によると、間口5～8間、奥行12〜25間の屋敷が全体の $60 \%$ を 占めていることがわかる。また間口と奥行が共にほぼ等しい屋敷も $35 \%$ ある。表間口は 6 7間が多数を占め、宿移転時の平均的な間口 規模として割り付けられていたことが推定される ${ }^{187}$ 。さらに寛文期 屋敷規模の特徴は、短冊形の細長い屋敷と、間口・奥行がほぼ等し い值をもつ非短冊形屋敷の、2 通りが存在することである。

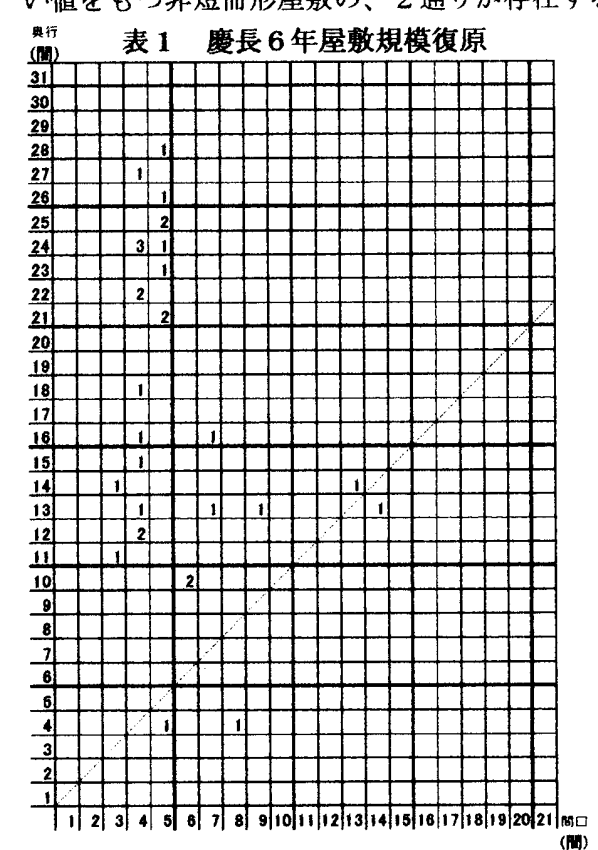

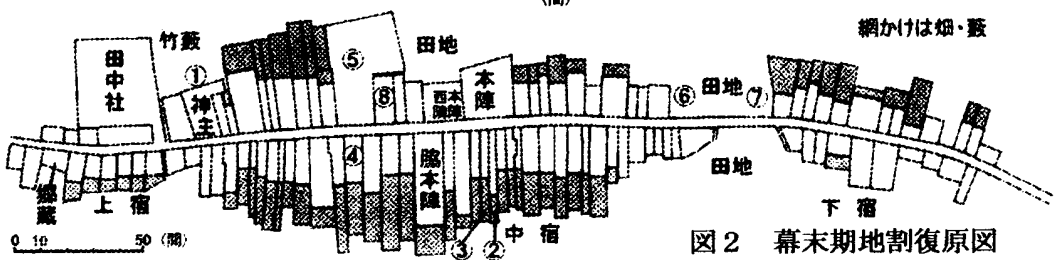

慶長期と寛文期を比較すると間口が狭く、奥行の長い屋敷は慶長 期の元宿において圧倒的に多数を占めており、むしろ移転後のほう が全体として間口の広いものが増加している。寛文 12 年では間口 5 間に満たない屋敷は 1 筆にすぎない。また、間口15間を超える大規 模屋敷は寛文期には 4 筆が記載されている。

\section{3 幕末の屋戟地割復原}

調查対象家屋の一棟、古屋家が所蔵する古絵図は古屋家当主名よ り幕末期と推定される史料であり、台ヶ原宿の屋敷地割の幅および 奥行の記載がある。この史料による幕末期の屋敷規模を表 3 に、ま た前述「北巨摩郡菅原村之内大字臺ヶ原 組全図」の地籍図に 1 筆ごとに落とし込 んで作成した復原図を図 2 に示す。

台ヶ原宿は上宿、中宿、下宿の三小字 から成り立ち、このうち上宿は田中 写真 1 古屋家古桧図(部分) 社 (神社)とその神主住宅を中心とする地域、中宿は本陣、脇本陣 ${ }^{(8)}$ 中心とする地域、下宿は上宿・中宿から耕作地を挟んで少し離れて 形成された地城である。本陣、脇本陣は現存しないが、現在の敷地 状況が基本的に幕末に注ほほ成立していたことが窅える。

寛文期の屋敷形態を留めながらも屋敷の分割が進展し、表 3 によ れば、寛文期に較べ間口3〜4間程度の狭小な屋敷群がかなり増加し ていることがわかる。これらは図 2 で宿・中宿の南側に形成され た狭小な屋敷群に過半 ${ }^{203}$ が該当する。間口 15 間以上の大規模屋敷は 表中に 3 筆、嘉永 7 年 (1854)には家相図により16間間口を確保して いたことが確実な表外 ${ }^{21)} の 1$ 筆(北原家・後述)を加えると 4 筆となり、 寛文期の筆数と同じである。4 間間口の屋敷が 1 筆にすぎなかった 寛文に較へ、幕末には間口3〜4間程度の狭小な屋敷群の増加221により、 台ヶ原宿における屋敷規模格差が顕在化していることが明確である。

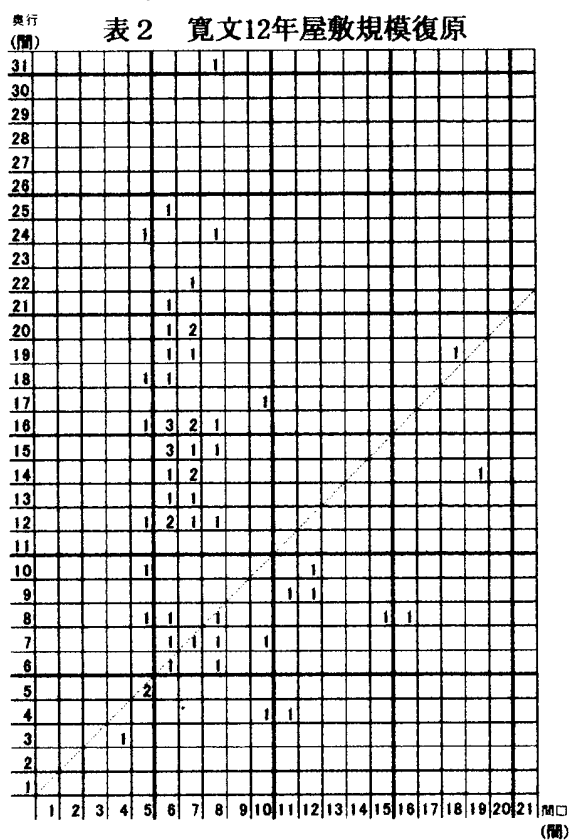

(踝)

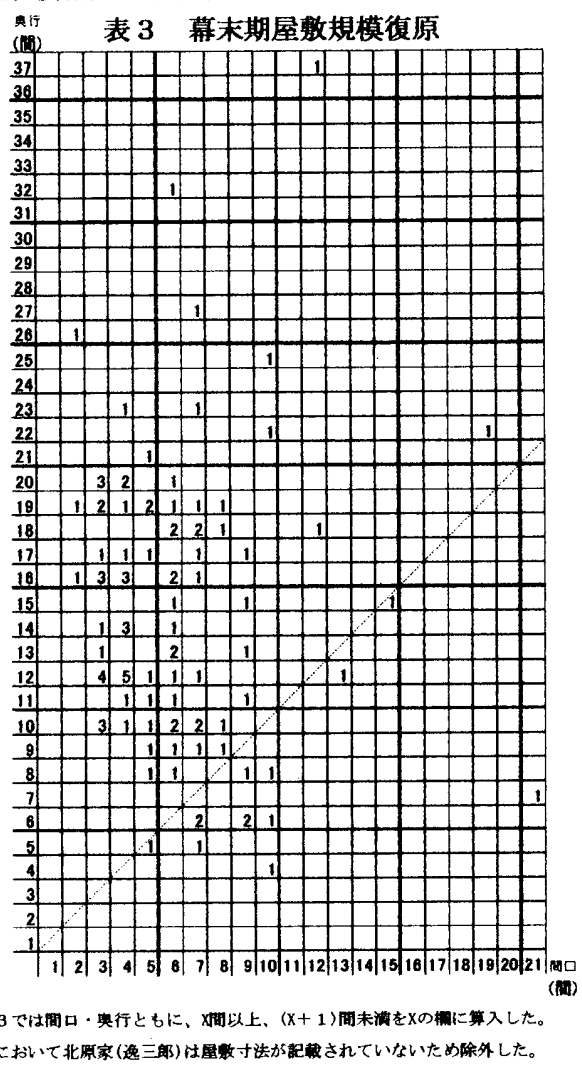


台ヶ原は明和年間から幕府・代官所御用の通行などの増加で宿駅 体制が強化され るが、この間の宿場の発展が現在の町並景観を特徴づけている。 なお図 2 中に実測調查の対象とした家屋 8 棟の位置を、表 5 (後述) の調查番号により記入する。(1)は表間口13間、(4)と8は8間、(5)は 16間と大きいが、(2)と(3)は間口3〜4間の細長い短冊形屋敷である。 また(6)と(7)は中宿と下宿の間の、明治以降に宅地化した敷地に建つ。

\section{3. 近世後期以降の土地所有状況の変化に関する考察}

寛文期の大規模屋敷 4 筆は間口19間 (奥行14間半・名請人仁兵衛)、 間口 18 間半(奥行 19 間・孫左衛門)、間口 15 間(奥行 8 間・甚右衛門)、 閒口 16 間 (奥行 8 間・御蔵屋敷)の 4 筆である ${ }^{24}$ 。これらの屋敷のうち、 最初の 2 筆は幕末期の名請人名により図 2 中の本陣西隣屋敷(幕末の 間口15間 2 尺) と本陣(同19間 4 尺)に相当すると考えられ き幕末期にも大規模屋敷足り得たと述べることができる。これに対 し、調查対象家屋の一棟、北原家は近世中期に他所よりこの宿に定 着、次第にその屋敷を拡大し、幕末期には大規模屋敷を形成した。 寛文期以来の大規模屋敷とは異なる性格をもつと言える。台ヶ原宿 の本陣・脇本陣は現存せず、北原家が最も大型の近世町屋遗構とし て町並の重要な位置を占める。ではその敷地はいかに確保されたか。 近世後期から幕末にかけての同家の土地集積過程を明らかにする。

\section{1 北原家について}

北原家 ${ }^{28}$ は、寛延 2 年 (1749) 頃、信州高遠栗田で酒造業を営んでい 表 4 北原家「屋敷」(宅地)変遷の経緯

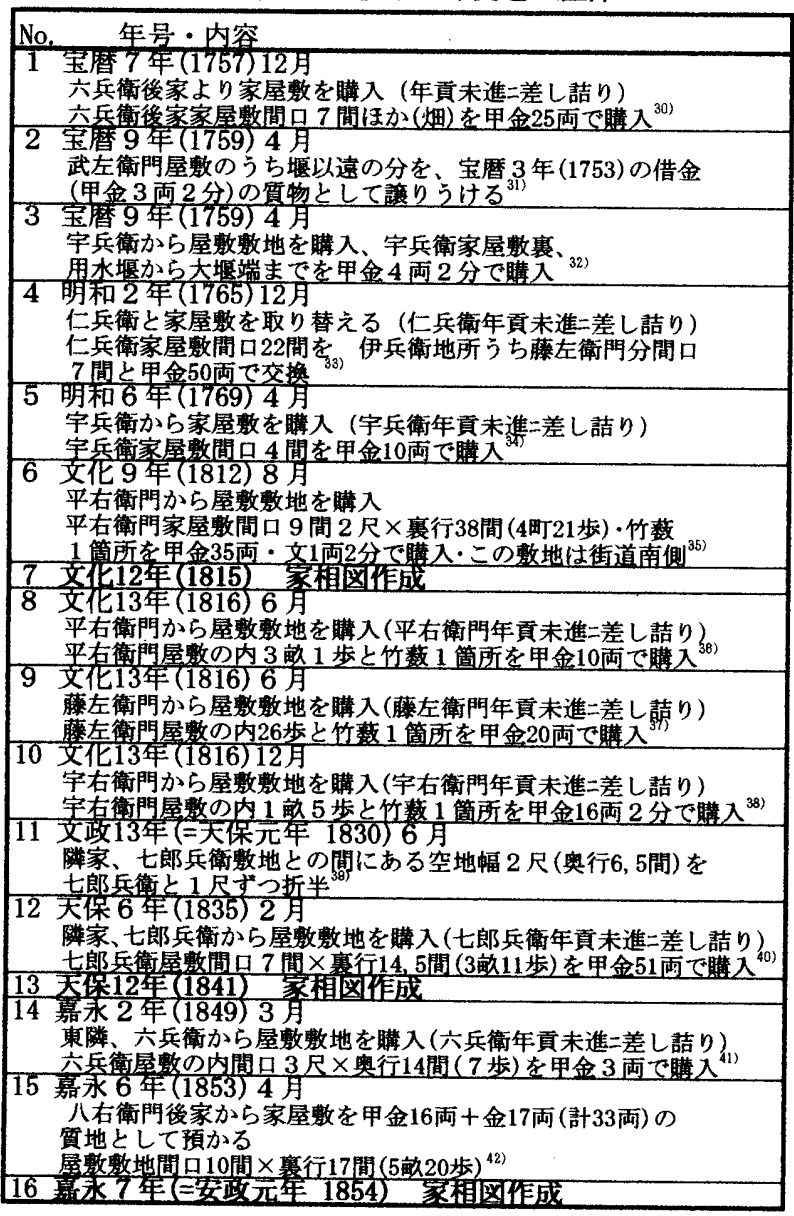

た北原伊兵衛 27 が台ヶ原に休酾中の酒屋があるのを知り、最初は觮 左衛門家屋敷を借家して、翌 3 年に創業したことに始まる ${ }^{28)}$ 。酒造 業は大きく発展して、幕末には諏訪高遠潘の御用商人となり大名貸 しを行うに至っている。明治13年に明治天皇が巡幸された際に、行 在所として使用され、現在は県指定の史跡に指定されている。

敷地は図 2 の(5に示すように、台ヶ原のほぼ中央、中宿にあり、 街道の北側に位置する。現在の建物は主屋の他に土藏、新主屋、酒 造工場、事務棟、従業員宿舎がある(図 3)。同家主屋は酒造業によ る富で築かれた、台ヶ原宿の大型町屋を代表する建物である。

\section{2 北原家の宅地集積過程の分析}

北原家には文化 12 年 (1815) 2 月上原以仙製の家相図、天保 12 年 （1841）5 月坪井民部製の家相図 (写真 2 )、嘉永 7 年 (1854) 坪井民部 製の家相図 (写真 3 )、慶応 3 年 (1867) 6 月大工棟梁宮川五郎製の 「北原氏境内百分一之図」の 4 点が伝存する。どの図にも敷地全体 が描かれ、主屋だけでなく後方付属屋についても詳細に知ることが できる。また同家には売券状も多数保存され、土地売買による敷地 形状の変化を推察することが可能である。売券状による屋敷 (宅地) の売買状況 ${ }^{28)}$ 表 4 に、家相図による敷地形状の変化を図 4 に示す。 北原家は宽延 3 年に台ヶ原に定着して以来、宝暦期より、次々と 台ヶ原の宅地を購入していった様子が表 4 から理解される。中でも 12 番史料の天保 6 年 (1835) 2 月、隣家七郎兵衛、14番史料の嘉永 2 年 (1849) 3月、東隣六兵衛からの各敷地購入は意味が大きかったと 考えられる。七郎兵衛が隣家であることは、11番史料に同じ七郎兵

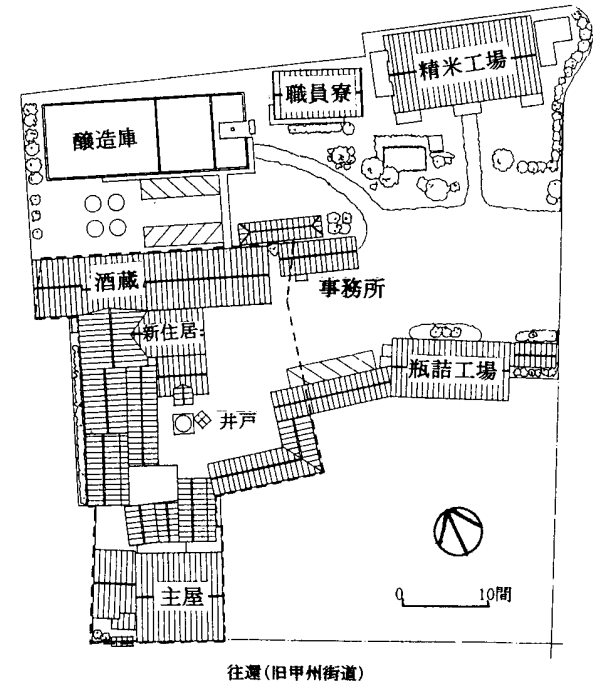

図3北原氏宅 現状配置図（太点線内は図 4 の嘉永敷地線）

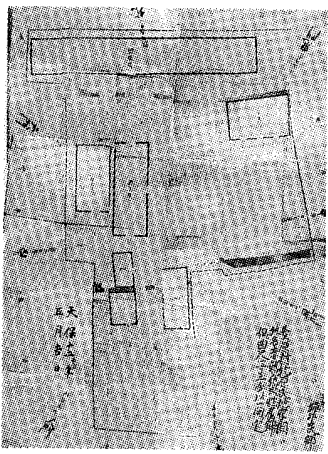

北原家天保12年家相図

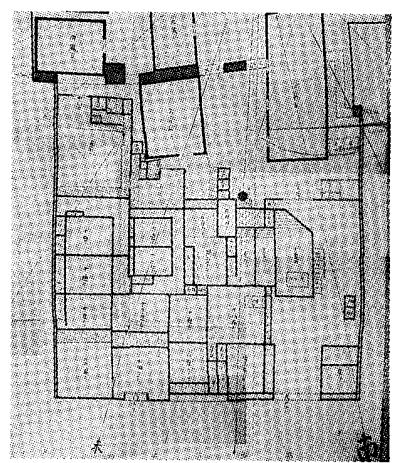

写真 3 北原家嘉水 7 年家相図 (部分) 
衛が「隣家」として記載されることからわかる。

このことは同家所藏の文化、天保、嘉永の3 面の家相図に示され る敷地状況 (図 4)により確認することができる。図 4 中、(1)の部分 が西隣、七郎兵衛より買い増した敷地であり、さらに(2)の部分が東 隣、六兵衛から購入した敷地に該当すると考えられる。天保 6 年お よび嘉永 2 年の敷地買得により屋敷の間口が増え、間口 (桁行) 16 間 $\times$ 奥行 (梁行) 10 間という現在の規模の北原氏宅の建設が可能となっ た。当家には天保 6 年に建てられたという伝承がある ${ }^{43}$ が、同年は建 設契機となった敷地の購入年を指すと考えられ、天保 6 年と伝承さ れるうちに土地の購入と建物の建設が混同されたものであろう。さ らに嘉氷 2 年の土地購入 ${ }^{44}$ により間口 16 間の敷地を確保したのである。

\section{4. 調查対象家屋の各戸解説}

それでは次に各町屋の建築実測調査にもとづき、台ヶ原宿を構成 する住居形式とその変遷を探る。各住居の建設年代は1700年から 1927年の間に分散しており、台ヶ原の各時代を代表する町屋として 実測調査対象に選定したものである。各戸の位置は図 2 に示した。

ここでは実測調查の対象とした 8 棟の解説を推定する建設年代の 古い順に述べる。これら 8 棟は、間口 $3 \sim 4$ 間程度の短冊形敷地に建 つ町屋 2 棟 (No. 2,3)、間口 $7 \sim 8$ 間程度の敷地 2 棟 (No. 4,8$)$ 、間口 10 間以上の敷地に建つ町屋 4 棟 (No. 1, 5,6,7)により構成されている。

\section{1 台原信氏宅（表 4 中No. 1)}

台原氏宅は田中神社 (図 2 参照)の神官を務めた家柄であり、関口

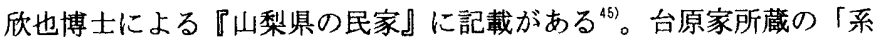
図」により、主屋は元禄13年 (1700)の建築と推定される。往還に面 して表門を構え主屋を奥に引いて建て、主屋は桁行 9 間 $\times$ 梁間 5.5 閒 平入形式の切妻・元板葷で、現在の居空は整形四間取の背面に納戸 のつく形態である。土間向かいに待合、板間、物置の三室が続く。 復原平面は三室広間型で、イマ奥のナンドは当初と考えられる ${ }^{48)}$

構造においては柱が 1 間毎に建てられ、柱上材を慗ぐ材が頭貫の みで、登梁が 1 間間隔で折置組に配されるなど、極めて古式を示す。

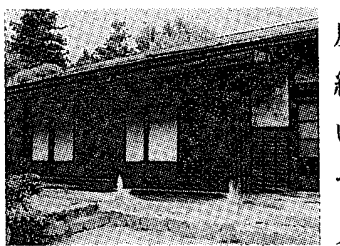
屋根は元来板蕞であったが、小屋組に束を 継ぎ足して屋根勾配を変え、鉄板薑として いる。社家住宅としての特殊性はあるが、 台ヶ原における住居形態の祖型のひとつと 写真 4 台原氏宅外観

4.2 鈴木卓雄氏宅（表 4 中No. 2)

当主からの聞き取りによると、鈴木家の先祖が寛政年間(1789〜 1801)の頃に、馬宿をしていた建物を居抜きで買い取ったものである という。従って建設年代は遅くとも1700年代後半と考えられる。

主屋は桁行 3 間 $\times$ 梁間 7 間、切妻・元板晜で現在鉄板瓦棒亘の平入 住宅である。敷地は間口約 $6 \mathrm{~m}$ に奥行 $76 \mathrm{~m}$ と細長い短冊状で、付属建物 も多い。表側から作業場、床下にヒジロの残る10畳、床付きの 8 畳 と三室が並び、幅 1 間の通り土間が通る。 8 畳の上部は元来ツシ 2 階であったが、大正期に棟の位置を 1 間半南側に変えて、2 階を広 げる改造が行われた。妻壁内側に旧垂木が、また10畳南の差物上束 (2 階)に梁大入れの痕跡が残る。通り土間の向かいには現在居間が あるが、聞取りではここが2間半四方のウマヤであり、元来馬主の便

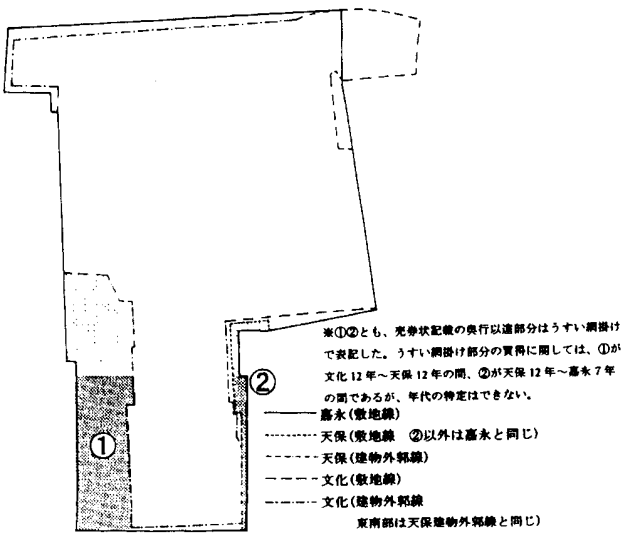

図 4 文化・天保・嘉永家相図による北原家敷地線

表 5 台ヶ原調查対象町屋一覧

\begin{tabular}{|c|c|c|c|c|c|c|c|c|c|c|}
\hline \multirow[b]{2}{*}{ 号 } & \multirow[b]{2}{*}{$\begin{array}{l}\text { 当主名 } \\
\text { (敬称略) }\end{array}$} & \multirow[b]{2}{*}{ 屋号·呼称 } & 聞 & \multicolumn{7}{|c|}{ 調 查 図 面 } \\
\hline & & & $\begin{array}{l}\text { 取 } \\
\eta \\
\text { 調 } \\
\text { 查 }\end{array}$ & $\begin{array}{l}\text { 階 } \\
\text { 平 } \\
\text { 面 }\end{array}$ & $\begin{array}{l} \\
\text { 階 } \\
\text { 平 } \\
\text { 面 }\end{array}$ & $\begin{array}{l}\text { 粱 } \\
\text { 行 } \\
\text { 断 } \\
\text { 面 }\end{array}$ & $\begin{array}{l}\text { 配 } \\
\text { 置 }\end{array}$ & 復 & 架 & $\begin{array}{l}\text { その他 } \\
\text { 図面 }\end{array}$ \\
\hline 1 & 台原信 & 台原莱局 & 0 & 0 & - & 0 & O & 0 & 0 & 地形断面 \\
\hline 2 & 鈴木卓雄 & 鈴木電気工事 & 0 & 0 & 0 & 0 & 0 & 0 & & \\
\hline 3 & 磯貝治男 & 嘰貝商店 & 0 & 0 & - & 0 & 0 & 0 & & \\
\hline 4 & 古屋博 & （特に筧し） & 0 & 0 & 0 & 0 & & 0 & & \\
\hline 5 & 北原兵庫 & 七㹂 & 0 & 0 & 0 & $\mathrm{O}$ & 0 & 0 & 0 & 立面·座数断面 \\
\hline 6 & 岡村喜代藏 & 岡村酒店 & 0 & 0 & 0 & 0 & 0 & 0 & & \\
\hline 7 & 細田敬三 & 永采屋 & 0 & 0 & 0 & 0 & 0 & 0 & & \\
\hline 8 & 渡辺郁男 & 没㮩料店 & 0 & 0 & 0 & 0 & & 0 & & \\
\hline
\end{tabular}

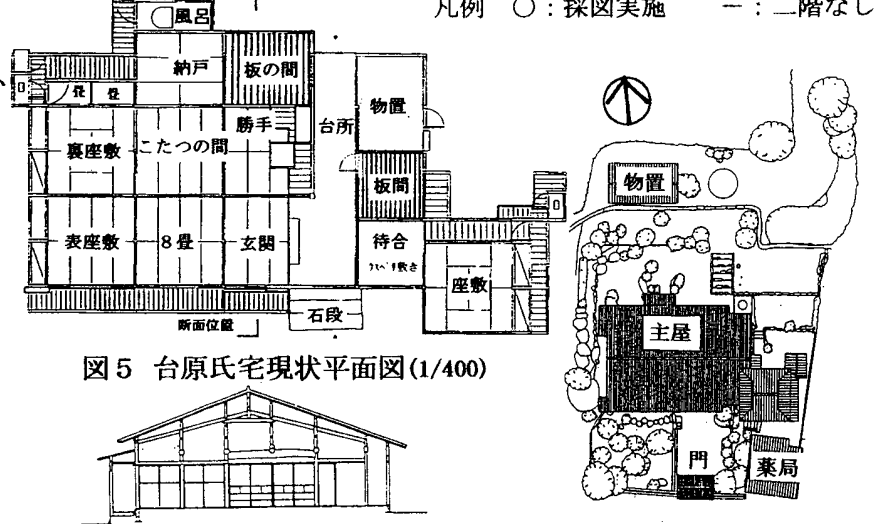

図 6 台原氏宅断面図 $(1 / 400)$

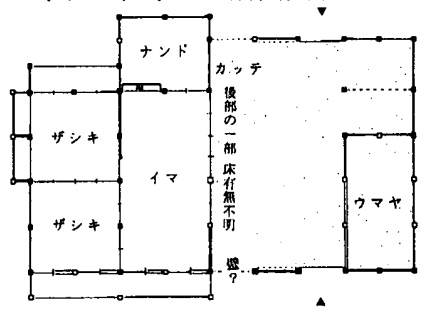

図 8 台原氏宅復原平面図 $(1 / 400)$

図 7 台原氏宅配置図

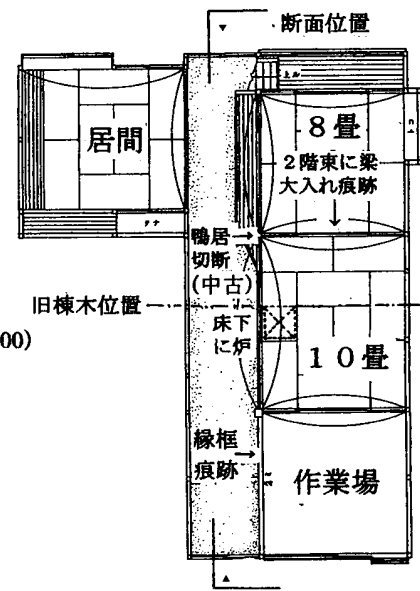

写真 5 鈴木氏宅外観

図 9 鈴木氏宅 現状平面図 $(1 / 250 \cdot$ 痕跡含 
宜のためにこの位置“7に設けられていたという。現当主の誕生に際し て大正12年、そのウマヤを居間に改造し、棟位置を変更する工事も 同時に行ったという。当初復原平面は、一列三室型と考えられる

\section{3 磯貝治男氏宅（表 4 中No. 3)}

磯貝氏宅は前述の鈴木氏宅西側に隣接し、同氏宅と表側軒高さ及 び屋根傾斜が等しく、間取が非常に似ていることなどから、鈴木氏 宅の建設に続いて、少しあとに建設されたものと推測できる。建設 年代は 1700 年代後半から、遅くとも1800年代前半にかけてであろう。

建物は主屋、離れ、物置等からなるが、増筑が進んで屋根も複雑 に重なる。主屋は現在桁行 4 間 $\times$ 梁間 11 間、切妻・元板蒀で現在鉄板 瓦棒草の平入住宅である。道路側に近年まで店舗として使用されて いた土間があり、屋根形状から、土間奥の寝室、居間までが当初の 主屋に納まっていたとわかる。昭和 40 年代から食料品・雑貨店を営 んでいたため、当時 8 盢の鲁敷きであった「ミセ」を土間に改造、 往還側にも半間ほど土間を拡張し、さらに現在の居閒の奥に子供部 屋、寝室、便所・風呂を増筑した。台所の東には流しが残るが、庇掛 けとしたこの外土間に罯もあったという。6 盢の居間には長押が回 り落し掛けが残り、元のザシキと推定される 4 間 $\times$ 梁閒7間で、復原平面は一列三室型と考えられる。

\section{4 古屋博氏宅（表 4 中No. 4）}

古屋氏 ${ }^{50}$ 宅には近年まで棟札が残り、当主の記録によるとそれには 「嘉永四年三月廿八日上棟」 ${ }^{51)}$ と記されていたという。

主屋は桁行7.5間 $\times$ 梁間6.5間の切妻、元板葺の平入住宅である。 現在、通り土間側に 8 畳 - 居間、反対側に表座敷 -中の間 - 奥座敷 (休の間付) が並ぶ。通り土間を挟んで 6 睤・勝手・台所がある。現 在の表戸口ほぼ中央と、そこより約 6 尺東のいずれも梁下端に柱当 たりの痕跡が残り、通り土閒が現在より約 3 尺ほど東にずれて通っ ていたことがわかる。聞取りによると、通り土間の東には往還側に イタマ、奥に現状より 3 尺幅の狭いカッテがあったという。さらに 奥座敷の東側、板の間との境中央に柱切断痕跡が残る。聞取りでは 板の間の位置に 8 眰の部屋があったというが、奥座敷境の柱切断痕 および、その南の柱 2 本に残る貫痕跡より、奥座敷と復原 8 畳の境 は壁であった可能性が高い。以上により、当初は二列三室構成であ ったと考えられる。小屋組は棟筋から前半分に 4 本の登梁を架け 2 階を設けており、前面は入側柱に腕木を差して出析造としている。 屋根は、勾配を 3 寸 5 分から 4 寸 5 分に変更して板莫から瓦莫に真替え た。当家は台ヶ原における寛文期以来の平均的な屋敷の間口規模、 5〜8間に対応する二列型町屋の典型とみなすことができる。

\section{5 北原兵庫氏宅（表 4 中No. 5)}

主屋の建築年代は 3 章で述べたように、同家に残された家相図お よび家相図を照合すると、嘉永 2 年 (1849) 7 年 (1854) の間と考え られる ${ }^{62)}$ 。土間上部には 8 間通しの豪快な梁組を見せ、台ヶ原宿を代 表する大型の町屋遗構である。

主屋は桁行16間 $\times$ 梁間10間で、屋根は切妻平入りの元板暮・現在 銅板惪である。主屋の西側析行 6 間分に 12 畳を含む座敷 6 室、東側妳 行10間分に店および広間、仏間、応接間、勝手、納戸、台所をもち、 西側部分は梁間7間で、東側部分から北西に突き出した鉤型をなす。

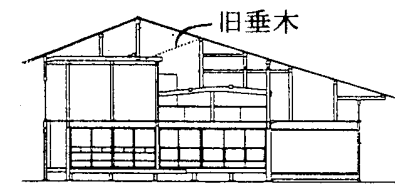

図10 鈴木氏宅断面図(1/400)

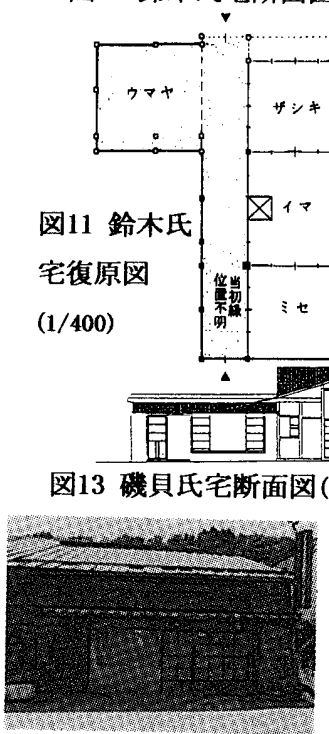

写真 6 磯貝氏宅外観

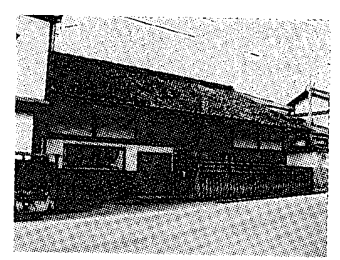

写真 7 古屋氏宅外䘽

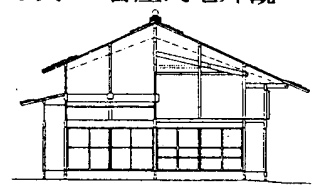

図16 古屋氏宅断面図(1/400)

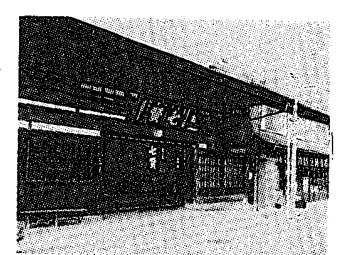

写真 8 北原氏宅外観

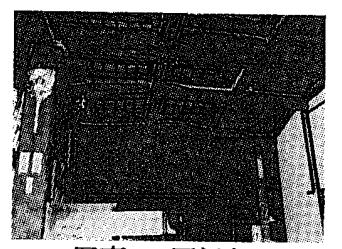

写真 9 同梁組

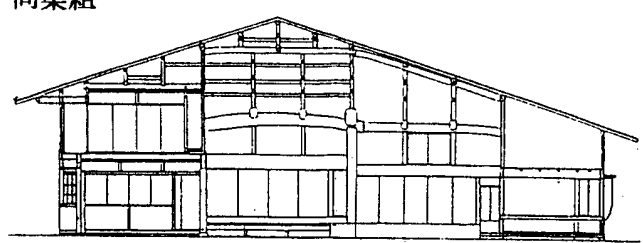

図19 北原氏宅土間部分断面図(1/300) 
また建物往還側に 2 階座敷、裏側の台所上部にはツシ 2 階が設けら れている。

前述した北原氏宅の家相図のうち、嘉永 7 年の家相図が現在の建 物の当初図面に近いと考えられ、当初の主屋規模は析行 16 間 $\times$ 梁間 10 間で、現状と同じである。また続く慶応 3 年の家相図は嘉永家相 に良く似ており、この間に大きな改造はなかったと考えられる。

嘉永および慶応の家相図によると、西側桁行6間分には、まず「十 二畳玄関」があり、その西に梁行に三室「十畳」が続く。現在はこ の三室を往還側から表座敷、中の問、行在所 ${ }^{53}$ と呼んでいる。その東 には庭先へと抜ける「入側」とともに二室続きの「六畳」があり、 ここが近年まで主人夫婦の寝室に使用された部屋であった ${ }^{54)}$ 。

東側析行10間には、通り土間の東側にシモミセに相当する部屋が あり、嘉水、慶応ともに家相図では酱油店としている。また土間(口 ジ)西側の「店十疊」、「仏間」南の「八畳」は現在それぞれ洋室の 展示室と応接室に改造されている。後年の改造が最も多いのは「台 所」および土間迴りである。当初復原平面は、二列三室の東側析行 10 間に二列三室の座敷列を付設する、大規模複合型である。

\section{6 岡村喜代藏氏宅（表 4 中No. 6)}

岡村氏宅の建設年代は棟札より明治24年 (1891) とわかる。当家は 酒屋を営み、主屋規模は桁行 6 間 $\times$ 梁間 5.5 間、瓦苦・置屋根形式の 蔵造町屋である。前面に店舗のための前土間を設け、座敷二室・旧 帳場・中の間・居間を設ける。居間の中央やや西よりの梁下端に柱 ないし束の痕跡があり、その南の柱に鴨居痕跡が残る。このため、 現在の居間恃二分されていたと考えられ、東側が元のイマ、西側は 聞取りによると通路(通り土間)であったという。またイマと土間の 境には柱に各溝 1 本が残ることから、填め殺しの建具が入っていた と推察される。現状の居間の裏に台所、風呂、便所等からなる増築 部分が張り出す。住宅としての出入りは、主屋脇の門を通り、妻側 の土間玄関から行う。当家を含め、妻側の土間玄関は前土間型とな る調査家屋にはすべて設けられており、この型の特徽でもある。

当初復原平面は、前土間型(二列二室) と考えられる。

\section{7 細田敬三氏宅（表 4 中No. 7)}

当家にも棟札が残り、建築年代は大正 5 年 (1916) と判明する。町 内の古家の材を利用し、建設した建物である。当家は大正中期に甲 信自動車運輸株式会社を創業し、現在は雑貨屋を営んでいる。

現在の主屋規模は析行7.5間 $\times$ 梁間10間で、屋根は瓦草、東側が入 母屋、西側が切妻となる。表側の梁間 5 間分を巨大な店舗空間として 前土間を設け、裹側の梁間4.5間が居住部分となる。前述した岡村氏 宅と同様、座敷二室・中の間・ 8 嘼を整形に配置し、居間・台所を 設ける。ミセは昭和40年頃に改造されており、往還側にもミセ土閒 を半間桩張した。当初は土間と板の間境は現在よりもさらに奥にあ り、通り土間が主屋の裏まで続いてい たと推測される ${ }^{55)}$ 。土間以外の改造は 少なく、復原平面は二列二室型の前士 間型であると考えられる。当住宅は明 治以降に宅地化された間口25閒の敷地 に建っている。

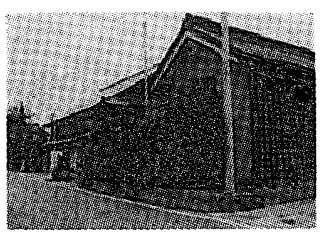

写真11 細田氏宅東側外锤
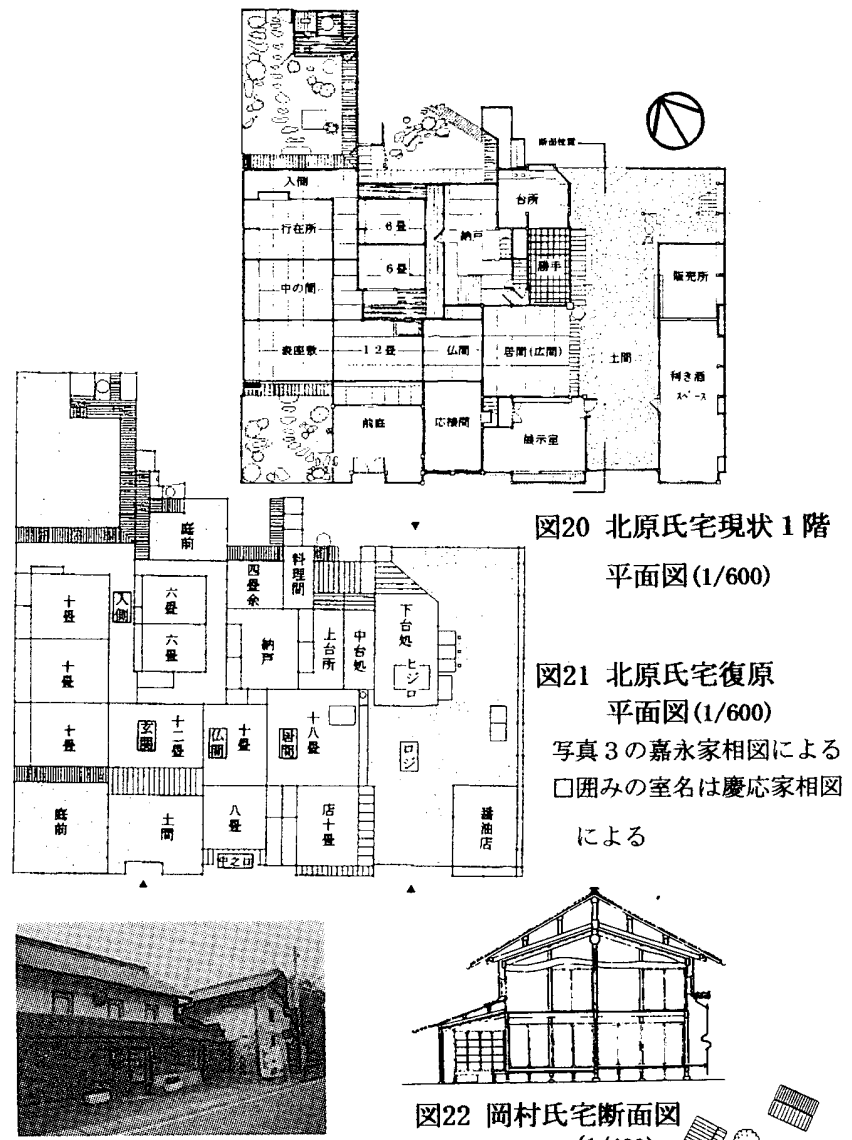

写真10 岡村氏宅外観

図22 岡村氏宅断面図 (1/400)
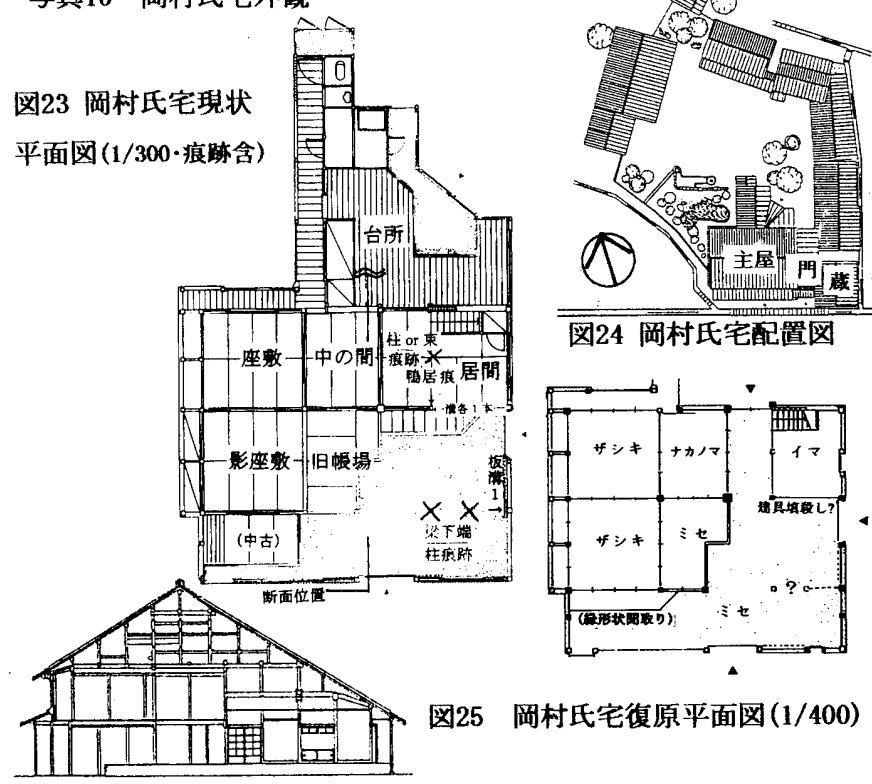

図24 岡村氏宅配置図

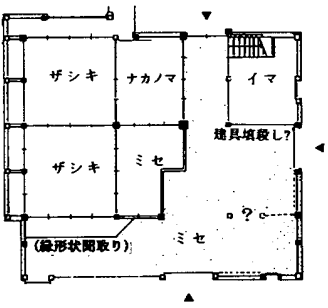

岡村氏宅復原平面図 $(1 / 400)$

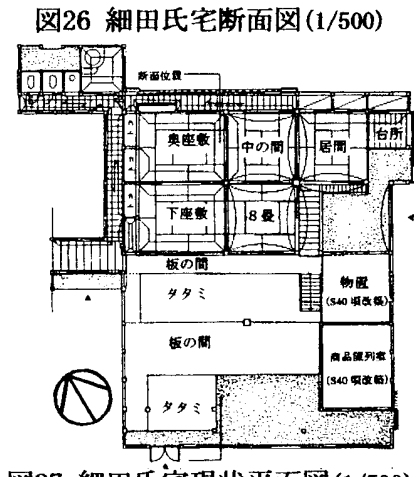

図27細田氏宅現状平面図 $(1 / 500)$

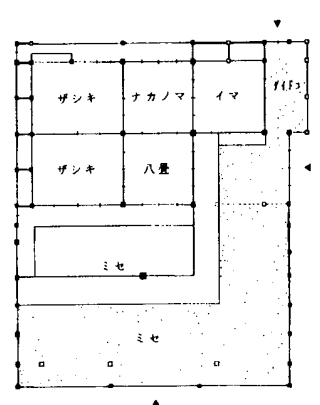

図28 細田氏宅復原平面図 $(1 / 500)$ 


\section{8 渡辺郁男氏宅（表 4 中No. 8)}

建築年代は棟札および䇋工写真が残り、昭和 2 年 (1927年) とわか る。大工は高橋保衛氏で、指物師は調查家屋NNo. 20当主、鈴木卓雄 氏の父である。当家は北原氏宅の東隣に位置している。

主屋規模は析行 7.5 間 $\times$ 梁間6間で、瓦莫の入母屋平入住宅である。 主屋 1 階の居室は、道路側にミセとして使用されている土間があり、 その奥は横一列に西から客間、中の間、仏間と三室続き、東側奥の 隅に4.5疊の居間がある。昭和59年に、主屋の裏に台所、応接間、便 所、浴室からなる別棟が増築された。聞取りによると、ダイニング キッチンの位置に各 3 轠大のダイドコと土間があったという。

当家は昭和期の建物であり、それ以外に大きな改造はされていな いようである。現在居間として使用されている部屋は、当初からイ マ $\left(\right.$ イド $\left.{ }^{58}\right)$ として使われており、基本的な生活の場は変化していな い。当初復原平面は前土間型(三室)である。

この時代になると構造形式はかなり進み、軸部の柱は均一となっ て、大黒柱もなくなっている。屋根は当初から瓦苟であった。

以上、No.6から8までの明治・大正・昭和の建築事例からは、ミセ 空間が拡大して前土間型が発生し、逆に居室部の規模が比率として 減少していくことがよく理解される。

\section{5.住居形式の変遷に関する考察}

以上、調查した町屋 8 棟の主屋について各々当初の平面形式を復 原し、屋根の形式とともに建設年代順に表 5 に示す。

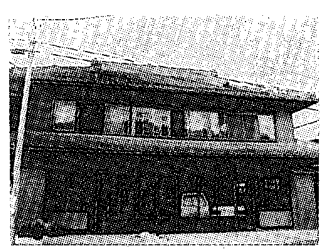

写真 12 渡辺氏宅外観

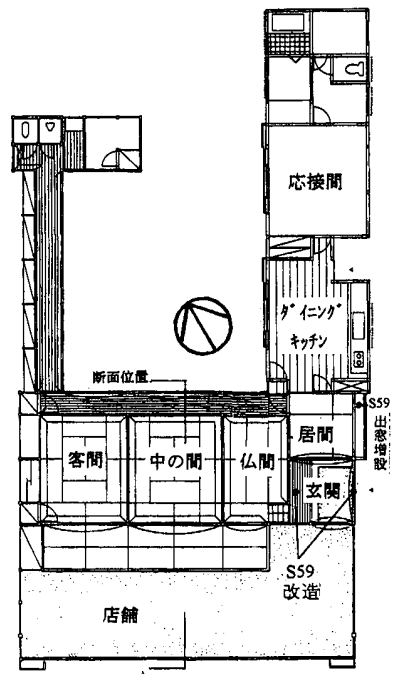

図30 渡辺氏宅現状平面図 $(1 / 400)$

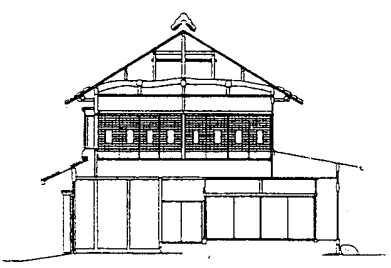

図29 渡辺氏宅断面図(1/400)

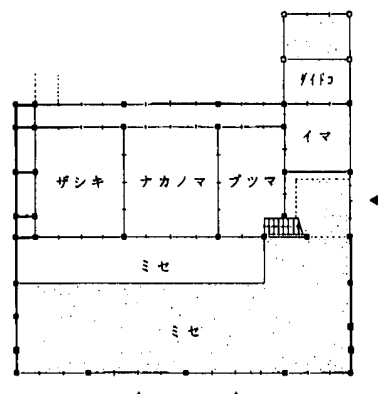

図31渡辺氏宅復原平面図 $(1 / 400)$

表 6 台ヶ原の調查住居に関する分析表

\begin{tabular}{|c|c|c|c|c|c|c|c|c|c|c|c|c|c|}
\hline \multirow{2}{*}{$\begin{array}{l}\text { 番 } \\
\text { 号 }\end{array}$} & \multirow{2}{*}{$\begin{array}{c}\text { 当主名 } \\
\text { (敬称略) }\end{array}$} & \multirow{2}{*}{$\begin{array}{c}\text { 当 初 } \\
\text { 主屋規模 } \\
\text { 桁×梁(間) }\end{array}$} & \multicolumn{3}{|c|}{ 居 室 } & \multicolumn{2}{|c|}{ 土間 } & \multirow[b]{2}{*}{$\begin{array}{l}\text { 妻 } \\
\text { 則 } \\
\text { 玄 } \\
\text { 関 }\end{array}$} & \multicolumn{3}{|c|}{ 屋 根 } & \multirow[b]{2}{*}{ 建 設 年 代 } & \multirow[b]{2}{*}{ 当初平面形式 } \\
\hline & & & 広 & 奥 & $\begin{array}{l}\text { 整 } \\
\text { 形 }\end{array}$ & $\begin{array}{l}\text { 通 } \\
y \\
\pm \\
\text { 間 } \\
\end{array}$ & $\begin{array}{c}\text { 前 } \\
\pm \\
\text { 丽 }\end{array}$ & & 形状 & $\begin{array}{c}\text { 罩材 } \\
\text { (当初 } \rightarrow \text { 現状) }\end{array}$ & $\begin{array}{c}\text { 勾配 } \\
\text { （当初 } \rightarrow \text { 現状） }\end{array}$ & & \\
\hline 1 & 台原 信 & $8.5 \times 5.0$ & 0 & & & 0 & & & 切妻 & 板 $\rightarrow$ 鉄板 & 2 寸 8 分 $\rightarrow 3$ 寸 7 分 & 元禄13年 (1700) 系図 & 三室広間型 \\
\hline 2 & 鈴木 卓雄 & $3.0 \times 7.0$ & & 0 & & 0 & & & 切妻 & 板 $\rightarrow$ 鉄板 & 3 寸 1 分 & 18世紀後半 聞取り & 一列三室型 \\
\hline 3 & 磯員 治男 & $4.0 \times 7.0$ & & 0 & & 0 & & & 切妻 & 板 $\rightarrow$ 鉄板 & 3 寸 1 分 & 19世紀前半 & 一列三室型 \\
\hline 4 & 古屋 博 & $7.5 \times 6.5$ & & 0 & 0 & 0 & & & 切妻 & 板 $\rightarrow$ 瓦 & 3 寸 5 分 $\rightarrow 4$ 寸 5 分 & 嘉永 4 年 (1851) 旧棟札 & 二列三室型 \\
\hline 5 & 北原 兵庫 & $16.0 \times 10.0$ & & 0 & 0 & 0 & & & 切妻 & 板 $\rightarrow$ 銅板 & 3 寸 3 分 & 嘉永2-7年 $(1849-54)$ 党获状·家相图 & 大規模複合型 \\
\hline 6 & 岡村 喜代蔵 & $6.0 \times 5.5$ & & & 0 & 0 & 0 & 0 & 切妻 & 瓦 & 5寸6分 & 明治24年 (1891) 棟札 & 前土間型(二列二室) \\
\hline 7 & 細田 敬三 & $7.5 \times 9.5$ & & & 0 & 0 & 0 & 0 & 入母屋 & 瓦 & 6 寸 2 分 & 大正 5 年 (1916) 棟札 & 前土間型 (二列二室) \\
\hline 8 & 渡辺 郁男 & $7.5 \times 6.0$ & & & 0 & & 0 & 0 & 入母屋 & 瓦 & 6寸 & 昭和 2 年 (1927) 竣工写真 & 前土間型(三室) \\
\hline
\end{tabular}

\section{1 平面形式の変遷について}

調查家屋の古い事例には台原氏宅(No.1)の三室広間型、鈴木氏宅 (No. 2) および磯貝氏宅(No. 3)の一列三室型の 2 通りの居室構成があ る。広間型は東日本の農家にも共通寸る平面形式であり、居室部が 桁行に 2 列並ぶために比較的広い間口が必要である。これに対し一 列三室型は甲信越地方の町屋として典型的な平面であり、間口が狭 く、奥行の長い敷地に適した平面形式である。

台原氏宅 (No. 1) は、建設当初の17世紀末には三室広間型であった が、後年の改造によって広閒に該当するイマは二室に分かれた。台 原氏宅恃建設当初よりイマ奥にナンドを設け、西の妻側にはザシキ が二室並ぶ形状である。これに対し近世末期建設の北原氏宅(No. 5) ははるかに大型化しているものの、イマとブツマの奥にナンドとダ イドコロを配置し、前面にミセを設け、座敷列を 2 列とした発展形
式とみることが可能である。

一方、一列三室型は磯貝氏宅(No. 3) の現状平面図に示したように、 間口が狭いままその奥に増築することが多い。基本的には街道側よ りミセ、イマ、ザシキと三空並ぶ。この奥行三室の型で間口が広い 敷地に対応したのが、古屋氏宅(No. 4)に代表される二列三室型であ り、これは台ヶ原の平均的な閒口に対応寸る町屋である。三室広間 型と一列三室型の形状は全く異なり、それから各々の住居形式が発 達したものとみられる。本稿の 3 章で明らかにしたように北原氏宅 は嘉永 $2 \sim 7$ 年の建設、また古屋氏宅は同 4 年の建設であるが、有 力家の町屋として幕末のほぼ同時期に建てられた両家が異なる祖型 をもつと考えられるところに、台ヶ原町屋の特色があるとみなすこ とができよゔ?

以上、近世の台ヶ原の住居形式は元来、通り土間をもつ平面であ 
ったと考えられるが、その後明治以降の住居では、ミセとして使わ れていた道路側前面の部屋を土間とする前土間型が見られるように なる。前土間型では岡村氏宅(No.6)や細田氏宅(No.7)のように、ミ セ空間が拡大するとともに居室部の規模は減少して、奥行二室構成 が一般的となっている。またイマ(イドコ)が小型化している点でそ れ以前の形式とは異なっている。近世の住居でほぼ梁行中央の土間 隣にあったイマは、近代の住居では前土間の発生とともに奥と移動 し、面積も䈹小化していく。渡辺氏宅(No. 8) は前土間型のうち、さ らに居室部分を二列から一列へと省略した事例であろう。このよう に近代的な商業形態に適応した新たな町屋形態が定着したのである。

\section{2 屋根の変化について}

台ヶ原の町屋は切妻平入で板惪とする屋根形式が一般的であった と考えられる。屋根が板蒙であった頃は傾斜も 2 寸 8 分 3 寸 3 分と緩 い。板苟の多くは、その後鉄板など金属板の屋根に薑替えられてい る。台原氏宅 (No. 1) や古屋氏宅 (No. 4)のように、屋根を莫替えると きに小屋束を補い、屋根傾斜を大きくする事例が見受けられる。

明治以降は前土間型の進展とともに、屋根傾斜を5〜6寸にした瓦 萁の町屋も増えたと推定され、さらに大正以降には細田氏宅(No.7)、 渡辺氏宅 (No. 8)のように入母屋・瓦莫の町屋も出現している。

\section{6. 結び}

以上のような台ヶ原の住居形式に対し、2 章で述べた屋敷(地割) との関倸性を含め、町並の形成に関して推察を行いたい。なお伝馬 宿である台ヶ原の住居として、古い事例も含めて町屋と総称する ${ }^{58)}$ 。

17 世紀末より18世紀後半頃までの台ヶ原の近世町屋の事例として、 三室広間型と一列三室型の 2 形式が現存する。寛文 12 年 (1672)の地 割において最多数を占めていた表間口6〜7間の屋敷には居室部が二 列になる住居が建設可能であり、この間口に対しては、広間型、あ るいは二列三室型のような居室部二列の町屋が対応すると考えられ る。近世中期までの町屋で奥行三空が成立していたかは確定できな いが、台ヶ原町屋の祖型の一つと考えられる1700年建設の台原氏宅 (No. 1)を見る限り、イマ(広間) 奥に当初からナンドが設けられてい たことが架構より明らかであるため、奥行三室となる十分な素地が あったと考えられる ${ }^{589}$ 。

一方、一列型は元宿から現在地への移転以前に圧倒的多数であっ た短冊形地割において、その祖型をもつと推測される。寛文 12 年の 検地帳では間口 4 間以下の屋敷は 1 筆のみであるが、近世中後期を 経て間口3〜4間の屋敷が増加したことが幕末期絵図より明らかであ る。18世紀後半の狭小な屋敷の基本的な住居形式が一列三室型であ ったと考えてよいだろう。

幕末の嘉永期には台ヶ原宿の平均的な屋敷規模をもつ古屋氏宅 (No. 4)に二列三室型の事例を確認できる。これとほぼ同時期、大型 屋敷には北原氏宅(No. 5) のような大規模複合型の町屋が成立する。 台ヶ原宿の近世町屋はこのようにして完成を迎えた。

さらに近代に入ると前土間をもつ間取が登場するが、この型は、 居室部が建物の奥になるため、妻側に立関をもつ。そのため往還に 面して主屋の並びに門を構え、ミセの出入りとは別に居住部へアプ ローチする形式をとる。岡村氏宅(No. 6) や細田氏宅(No. 7) は明治以 降、中宿と下宿の間にあった耕作地を宅地化し、間口の広い敷地を
確保した例であるが、いずれも往還に対して主屋、門、蔵を構えて おり、近世町屋とは異なる形で町並を構成している。経済的な最盛 期であった明治、大正期に台ヶ原宿の町屋はさらに発展し、現状の 町並を形成するに至ったと考えられる。

本研究を進めるにあたり、横浜国立大学の関口欣也名誉教授、千 葉大学の玉井哲雄教授にはさまざまな点でご指導、ご教授いただい た。また実測および文献調査では、山梨県教育委員会の林陽一郎お よび鷹野幸雄の両氏、調查当時学部 4 年生であった国岡和樹君 (現在 三井木材工業勤務)、原拓已君 (現在東北職業能力開発大学校講師)に 協力いただいた。数回に及ぶ調查を快く受汁入れて下さった台ヶ原 の住民の方々へも、記して梁く感謝の意を表したい。

\section{【後註】}

1) 面達人編：改訂新編相州古女書 第一巻 一七二号 角川書店 p. 1441965

2) 府中とは武田家の戦国期城下としての甲婓府中 (甲府)を指す。近世になると南東部に甲府 新城下が䈎かれ、もとの府中は古府中・上府中と称された。

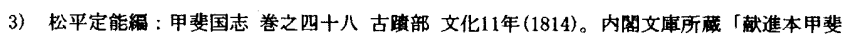
国志」を底本とする「大日本地詰体系 甲斐国志」第 2 巻 雄山阔 pp. 316-317 1970による。

4) 近世における五街道は度長 6 年 (1601)にまず東海道に伝馬制を定め、翌 7 年から中山道、 奥州道中、甲州街道、日光道中が顸次整備されていき、甲州街道については元和 4 年 (1618) に宿声が申し活されたという。(白州町誌絀舞委員会絀: 白州町詰 白州町 p. 309 1986)

5)白州町台ヶ原 北原兵庫家所藏文書。なお図146北巨摩郡菅原村之内大字台ヶ原組全 図」に添付された字界図による小字名を記入した。図中の1間は 6 尺計算で表記している。 6) 白州町誌編筷委員会編: 白州町誌 白州町 pp. 406-408 1986

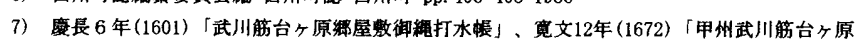

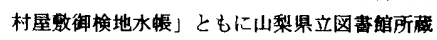

8）本稿は下部に発表した内容を整理統合し、その後の知見を加えて加筆・修正したものであ る。国岡和槽・原拓己・渡辺洋子：旧甲州街道台ヶ原宿の北原家住宅の建策と史料に関する 調查研究 倳業能力開発大学校紀要, 第26号A, pp. 13-25, 1997,3月

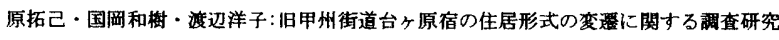
倳業能力開発大学校紀要, 第27号A, pp. 95-107, 1998, 3月

山梨県教育委員会䋧:山梨県史 文化財稂 pp. 282-285 伊藤裕久:台ヶ原の町並と住居

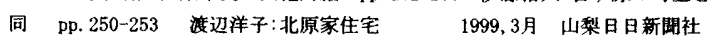

9）本稿の表題である「旧甲州街道」とは、度長 7 年頃と推定される整備後、昭和 34 年の台風 被災後の再整偏を経るまでの近世を中心とする甲州街道を指す。

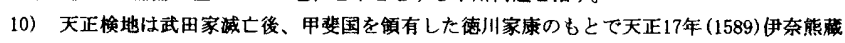
が開始し、「熊藏紻」等と称される。翌18年、家康の関東移封によって甲斐国が瞣臣家の所 㴭となり、文禄 3 年 (1594) 入部した五奉行の一人浅野長政(弹正少第)によって実施された模

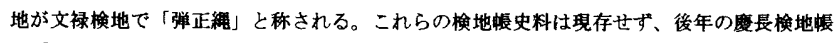
に「熊蔵荒」「弾正荒」などの書き込みが見られることで、两检地について推察するほかは ない。(磯貝正義・飯田文弥: 山梨累の歴史 山川出版社 pp. 150-152 1973)

11）慶長㛟地は関ヶ原の戦後、平岩親吉が再度徳川家康の城代として甲斐に入国すると、そ の下で大久保長安が奉行となって夷施したもので、「石見㛟地」と呼ばれ、村数722力村、 石高24万1662石余と集計されている。(註10前揭葏 pp. 152-153)

12）白州町内では台ヶ原、白須、大武川の三力村に屡長模地帳が完全なものとして残ってい

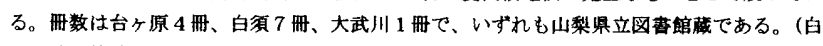
州町誌編策委員会稂: 白州町誌 白州町 pp. 276-278 1986)

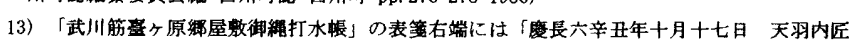
助岡部彦六」、表㩆を挟んで左端には「四番四冊/内案内仁兵衙彦三郎」とあり、こ の検地が天羽内匠助と剛部彦六によって、地元の仁兵衛と产三郎を案内人として実施された ことを示す。史料内部に仁兵衛は 22 坪屋軗の、彦三郎は 120 呯屋敷の各名読人として記载さ

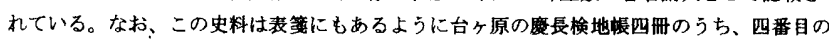

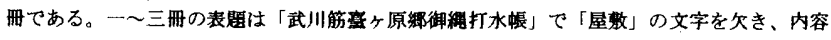
も田畑、すなわち耕作地について記載・集計している。屋教は最終冊である四番目の「武川

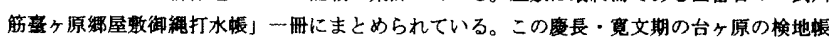
については、白州町誌に紹介され、耕地の名請状沿に関する分析がなされている。(白州町

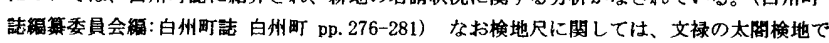
は 1 間が 6 尺 3 寸、德川氏の慶長年間以降の検地では、1間が 6 尺とされている。(北島正 元編：土地制度史 II 体系日本史新 7 pp. 48-55 山川出版社 1975)

14）史料嘼頭部の記载は「拾壱間 三間 屋鋪 三拾三坪恝四郎」から始まり、11間 $\times 3$

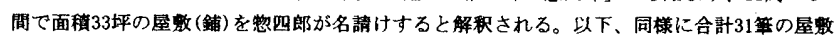
が記载さ九、その最後に「屋䑤合武千九百六拾坪此反九反八廿廿步」として屋敷の面皘を 集計している。なお、そのあとに「右之外御免之分」としてほ拾間十六間 同(二屋教: 策者注) 四百八拾坪御菜屋教」および「甘間拾三間同武百六拾坪石上庵寺中」 の除地 2 筆を記载している。本文中の表 1 にこれら除地 2 啭は算入していない。

15）白州町誌螎算委員会編: 白州町誌白州町 1986 pp. 831-834および. 312 。人馬継立方式は

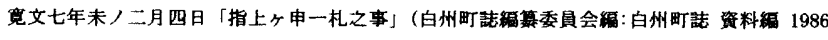
pp. 425-426所収)に基づき、䙾女 7 年(1667)に成立したとしている。 


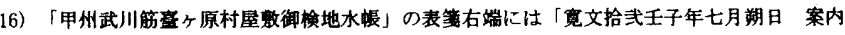
者 半左衛門 傳右衛門 与兵衛 兵左衛門」、表题を挟んで左端には「八冊之内八番 朝 比奈八郎右衛門」とあり、この㛟地が朝比奈八郎右衛門によって、半左衙門ら四名を案内人

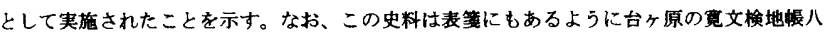
冊のうち、八番目の冊である。慶長検地帳と同倳、一〜七冊では田妞について記载・集計し、 屋數については最終冊である八番目の「甲州武川筋票ヶ原村御検地水帪」一冊にまとめる。

17）史料冒頭部の記载は「五間 八間 屋教壱腩拾歩 兵三郎」から始まり、5間 $\times 8$ 間で 面糟 1 站 10 歩 $(=40$ 歩 (坪) )の屋教を兵三郎が名誈けすると解釈される。以下、同様に合計 58

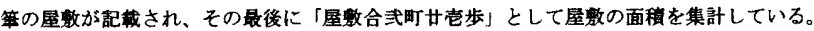
なお、この史料には除地の記戴はない。

18）表間口の割付に関しては、甲州街道㔨崎宿や同じ白州町内の教来石宿においても竟文换

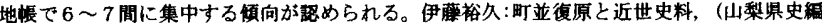
さん室編: 山梨紧史研究第 9 号 2001 pp. 32〜56)

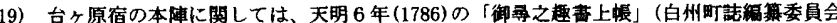

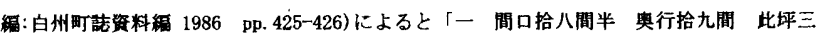
百五拾壳坪 建评九拾式坪 本陳 弦左衛門 一 間口拾壱間 奥行三拾六間 比坪三百九

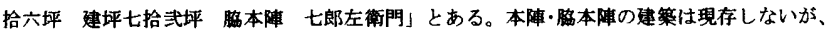
各々の教地位雷は現状で確詪できる。

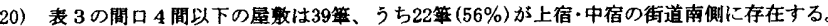

21）写真 1 の古屋家古絵図には、北原家位圈に较当する「逸三郎」分の地割に間口・奥行記 载がないため、表 3からは除外してある。なお「北巨摩郡营原村之内大字台ヶ原組全図」に

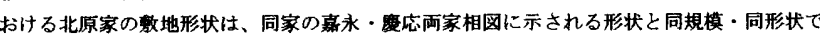
あるため、図2に打汀北原家の敫地(河)は「全図」の形状をそのまま表記してある。

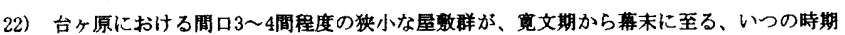
に増加したかは明らかでないが、平均的な閶口6〜7間が 2 筆に分筆されることで生み出され

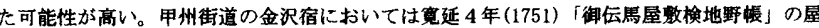

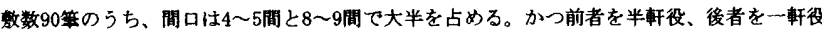
として軒役数を記载している。(註18前揘論文)

23）白州町誌p. 407の記载では、「天明三年の「台ヶ原教来石宿助成願」によると、甲府以西

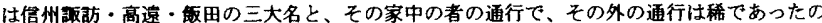
で、宿民は四月から八月は主として農耕に従事していたのである、即ち村方主、宿方従とい う宿駅の性格がうかがえる。」としている。しかしながら、その後、明和年間からの通行 增加で宿駅整備を迫られるに等る。

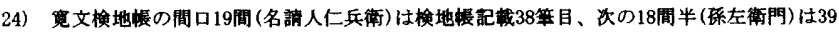

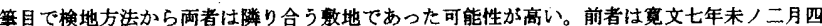

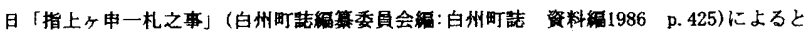
甲州 台ヶ原 問屋 仁兵衛」とあり、寛文 7 年(1667)に台ヶ原宿の問屋を勤めた家であ

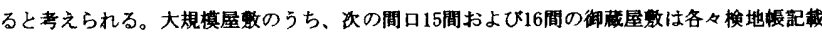

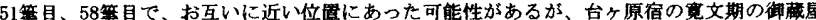
䑤に関する史料が管見に入らず、場所を確定することは難しい。なお、図 2 の幕末期地割復

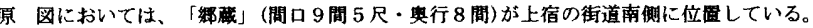

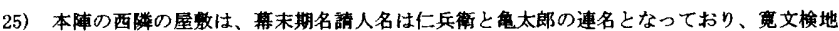
帳の間口19間(名請人仁兵衛)の屋敷にほほ比定される。北原家所藏文書中、表 $3 の 4$ 番史料 に示す明和二年乙西十二月「年々御年貝御未進二差詰皮夕組替申家屋敷之事」によると、

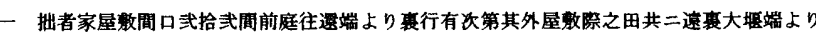

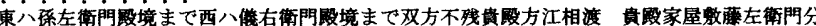

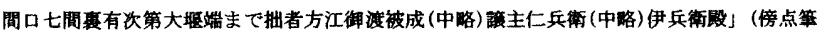

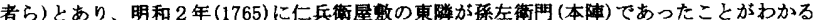
従って、竟文期の間口19間 (仁兵衛) 屋㪙、18闌半(孫左衛門) 屋教が明和 2 年にも同じ名請人 名で並んでいると理解できる。なお仁兵衛は文面の通り、明和 2 年に一旦、自分の家星敷を

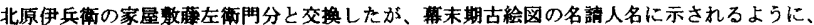
幕末に汒再度、本陣西隣屋教に戻ったと推定される。

26）北原家に関しては先行研究として 関口欣也：山梨県の民家(山梨県教育委員会編 第一 法規出版 1982)に詳細な記述があり、本研究でも参考とした。

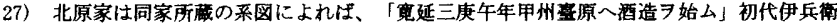
から五代の当主が伊兵衛を名秉っている。

28）北原家所蔵、明和三年成十月「差上申消御證女之事」によ九は「藤左衛門家屋敬借家仕

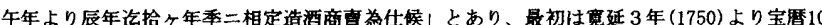
年 $(1760)$ までの10ヶ年舟で酒造を開始したという。この10年の間に伊兵衛は「家屋敷買求」

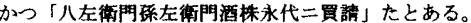

29）売券状の5ち田㚼など耕作地、竹萭に関するものは対象外とした。

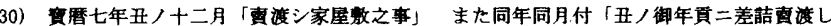
申屋教之事」にて、長兵衙屋教間口三間を甲金四禹で睡入しているが、後年宇兵衙に壳却し たと北原伊兵衛の添え書きがある。

31) 兾糜九年卯，四月「指出シ申一札之事

32）磿九年卯四月「賣渡シ申一札之事

33）明和二年乙西十二月「年々御年貢御未准二差詰皮々組替申家屋數之事」註 24 に述へたたよ 5に、兵衛と組替えたこの屋敫は、橖末に再ひ仁兵衙の所有となっている

34) 明和六年井/四月「年々御年貢御未進二差詰り水々吉渡シ申家屋教之事

35）文化九年申八月「撞洨申家屋鋪手形之事

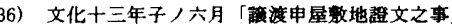

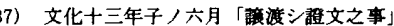

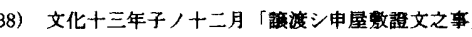

39）文政十三年宙六月「取替申居屋鋪境之事

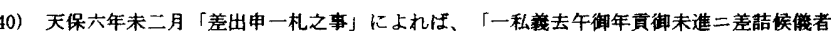

不及申 是迄年々借用金相告御百姓相繶難相成候二付 贵殿江御無心申居屋鋪表間口七間重

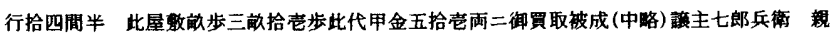

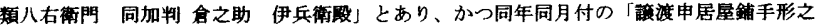

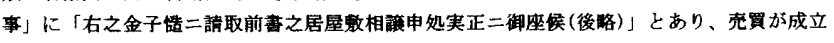
したことがわかる。

41）嘉永二年西三月「僙洨申屋数證文之事」によれば、「一甲金三両也 西之方二て 間口

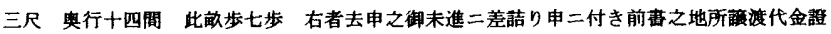

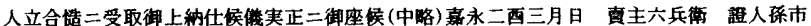
同村伊兵衛殿」とあり、六兵衛地所うち西之方の間口 3 尺、奥行14間分 ( 7 歩) の屋䑤を甲金 3 両で鿁ったとしている。

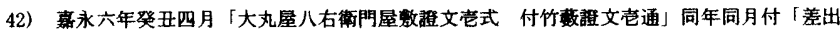
申一札之事!、「居屋鋪蜜地證文之事!

43) 当家に所藏される文化 12 年 (1815)、天保12年(1841)、嘉氷 7 年(1854)、鹿応 3 年 (1867) の 4 面の家相図のうち、主屋平面を中心纪見ると、文化 12 年家相図は前身建物の图面、天保 12年家相図は建筑前の主屋計画案であり、嘉本 7 年およひ慶応 3 年家相図が見存建物が完成 後の状况を示している。これは寸でに関口所也:山梨県の民家(註26前揭書) pp. 205-206に おいて明らかにされた通りである。当家には天保 6 年建設の伝承があるが、天保 12 年家相図 は主屋間口13間の建物で、現在のものと規模・間取りが異なることから、関口博士は当家の 建設年代を天保末年としている。しかしながら、本論で明らかにしたように実際には嘉承 2 年の土地買得がなけれ澗口16間の現主屋は建設不可能である。従って、当家の建設年代は 嘉永 2 年の東瞵からの土地睡入後、現在の主屋を描いた嘉永 7 年の家相図が作成されるまで の期間に絞られると考える。

44）註43の通り、天保 12 年家相図は現主屋建設前の計画案と考えられるが、同図中には後年 と推定される加篻があり、嘉承 2 年䀧入の間口 3 尺・奥行14間に該当する数地位圈を示す。

45）関口欣也:山梨県の民家(社26前揭書) pp. 203-204 p. 317による。

46）台原氏宅の復原に閶しては、「山梨県の民家」に記载のある関口博士の復原に依执した。 なお、本研究では現状での室名を主に漢字表記、復原での空名をカタカナ表記として区別す る。但し、家相図記载による室名は史料記载通りとする。

47）開取りによると、鉿木氏宅の「馬宿」ではウマヤ上部が吹抜けとなり、また宿泊客は土 阔向かいのザシキ上部のツシ 2 階に就寝して、2 階土間境に設けられたマドより土間越しに 馬の状況を見ることができたという。

48）鈴木家では通り土間を抜けた先の炊事場に流しがあり、拥理はここで行う(因12)。炏事 場下には旧吞用水が流れており、元来炏事はこの場所で行ったと考えられる。

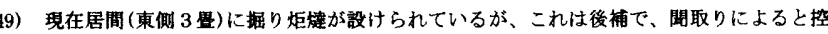
宰と呼ばれている部屋の中央にかって妒があったという。

50）古屋家ての闑取りによると台ヶ原宿で「古屋」姓を名秉る家系は元来武川腺の家臣団と して、「根古屋」に住み、台ヶ原の移転に伴って現在の宿に移住、この時「根古屋」の根の 字を除き「古屋」と名乗るようになったという。拥查家屋NNo.19台原家についても註45前揭 書に「姓を山高から称古屋・大河原・台原とかえ、慶長九年(1604)より古座姓としたとい う」とあり、漠字表記は異なるがネゴヤという姓から他姓を程てフルヤとしたとする。一方 古屋家の当主名は八左衛門が多く用いられており、宽文 12 年榙地帳の名請人、乌真 1 k示し

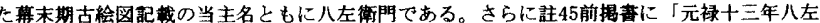
御門与屋教习替ル 家作出ル(ママ)」とあり、台原氏宅建設当時の古屋家との関連を示す。

51）古屋家現当主による忘備錄には「嘉永三年二十七日（双夜類焼に遭5 同四年家作三月 廿八日上楝」とあり、この時の古屋家当主は文化 5 年 (1808) 生まれの和吉義衙であったとい 5。白州町誌編算委員会綱: 白州町誌资料編 pp. 62-64k揭载されている「嘉水二年西八月 烧失拝借金贷洨證文」によれば、「去申年宿内両度之㜔失二付」洋借金を受け取ることにな った住民の中に「洋借人 和吉」とあり、火災は嘉氷三年ではなく、湓文文中にあるように 嘉永元年申年の聞違いではないかと考えられる。拝借金を受け取ったのが嘉氷二年八月であ り、嘉永四年三月に現家屋が上楝したと考えるのが妥当であるう。なお和吉義衙の息子が幕 末期古絵図に記截された八左衛門 (照時・明治21年没)である。

52）註43参照。

53）明治天皇が巡幸の際に使用したことにより最奥のザシキは行在所と呼ばれる。この住宅 は山梨殞の史跡に指定され、かつ平成10年 3 月13日付で町指定文化財の指定を受けた。

54）平成 6 年、䑤地内に新主座を建てて居を移したため、見在この座㜞は使用されていない。 55）細田氏宅断面図に示すように、ミセについては柱位置が 2 階物県の柱位圈とずれており、 転用材による建策であるために復原は極めて難しい。現状での土間にある板の間東の 6 冨と その北の4.5䡒は、聞取りによるともと土間で、昭和 40 年頃商品陳列と収納のために作った という。この時街道に面した建具位㨁を 2 尺前面に変更した。白州町誌稨算委員会編: 白州 町誌 p. 856所载の「大正八年 台ヶ原菲崎バス」の军真には建設後間もない細田氏宅が军っ ており、当初の街道側建具位置を確記できる。なお同じ写真が当家にも所藏されている。

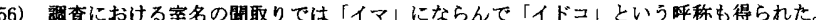
建築大辞典」によ扎ばいど 居所」の(2)として「山梨県北巨摩郡、長野県南安量郡地方 の民家で居間、莱の間」とある。(下出源七編 : 建寨大辞典 彰国社 p. 82 1974)

57）一列三室型と三室広間型の大きな相遣は、前者にはナンドとして復原される独立した部 屋が無いことである。二列三室型の古屋氏宅は闑取りでは中の間が元来の寝空であるが、奥 坐數への入りロでむあり、台原氏宅や北原氏宅のナンドとは異なっている。

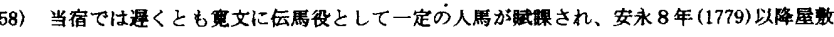

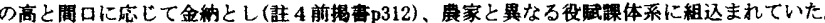
59）甲州街道の他の宿でも奥行二空型から三窒型へと、オクへ間取を発展させる町屋事例が 報告されている。例えば鳥沢宿では、二列二空型の町幄形式からオクへの発展過程を経て二

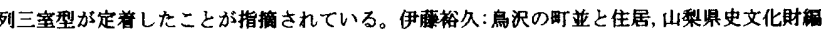
山梨日日新闕社 pp. 286 289 1999, 3月

（2000年 7 月 10 日原稿受理，2001年 6 月 19 日採用決定 